\title{
Studi Retrospektif Gambaran Resistensi Bakteri terhadap Antibiotik
}

\section{Retrospective Study of Antibiotic Resistance Profile}

Ni Kadek Sukertiasih ${ }^{1}$, Fitria Megawati ${ }^{2 \bullet}$, Herleeyana Meriyani ${ }^{1}$, Dwi Arymbhi Sanjaya ${ }^{1}$

${ }_{1}^{1}$ Program Studi Sarjana Farmasi, Fakultas Farmasi, Universitas Mahasaraswati Denpasar, Kota Denpasar

2Program Studi Diploma Tiga Farmasi, Fakultas Farmasi, Universitas Mahasaraswati Denpasar, Kota Denpasar

Abstrak: Menurut Center for Disease Control and Prevention resistensi bakteri terhadap antibiotik masih menjadi masalah kesehatan global. Tingginya angka kejadian resistensi bakteri terhadap antibiotik memerlukan suatu upaya pengendalian penggunaan antibiotik. Pengendalian penggunaan antibiotik bertujuan untuk memberikan informasi pola penggunaan antibiotik yang lebih bijak yang dapat dilakukan dengan cara mengaudit jumlah penggunaan antibiotik di rumah sakit. Tujuan dari penelitian ini adalah untuk mendeskripsikan profil resistensi antibiotik. Penelitian ini merupakan penelitian non eksperimental dengan desain deskriptif. Pengumpulan dilakukan secara retrospektif dari persentase resistensi antibiotik selama periode 2019 - 2020. Penelitian ini dilakukan di Rumah Sakit Umum Pemerintah Denpasar. Sampel penelitian ini adalah data peta kuman periode 2019- 2020. Bakteri gram positif yang paling banyak menyebabkan infeksi adalah Staphylococus Coagulase Negative (43\%), Enterococus. sp (10\%), Staphylococcus aureus (36\%). Selain itu, terdapat tiga bakteri Gram negatif yaitu Escherichia coli (32\%), Pseudomonas aeruginosa (12\%) dan Klebsiella pneumoniae (12\%). Berdasarkan profil resistensi, antibiotik yang direkomendasikan terhadap Gram positif adalah antibiotik ampisilin sulbaktam, siprofloksasin dan levofloksasin. Sedangkan antibiotik yang direkomendasikan untuk melawan bakteri Gram negatif adalah Sefoperason Sulbaktam dan Sefepim.

Kata Kunci: antibiotik, bakteri, persentase resistensi.

Abstract: According to the Center for Disease Control and Prevention, bacterial resistance to antibiotics is still a global health problem. The high incidence of bacterial resistance to antibiotics requires an effort to control the use of antibiotics. Controlling the use of antibiotics aims to provide information on patterns of wiser use of antibiotics which can be done by auditing the amount of antibiotic use in hospitals. The purpose of this study was to describe the profile of antibiotic resistance. This research is a non-experimental research with a descriptive design. The collection was carried out retrospectively from the percentage of antibiotic resistance during the period $2019-2020$. This study was conducted at the Denpasar Government General Hospital. The sample of this research is the data of the germ map for the period 2019-2020. The most gram-positive bacteria that cause infection are Coagulase Negative Staphylococci (43\%), Enterococcus. sp (10\%), Staphylococcus aureus (36\%). In addition, there are three Gram negative bacteria, namely Escherichia coli (32\%), Pseudomonas aeruginosa (12\%) and Klebsiella pneumoniae (12\%). Based on the resistance profile, the recommended antibiotics against Gram positive are ampicillin sulbactam, ciprofloxacin and levofloxacin. While the recommended antibiotics against Gram-negative bacteria are Cefoperason Sulbactam and Cefepime.

Keywords: antibiotics, bacteria, percentage of resistance.

\section{PENDAHULUAN}

Permasalahan resistensi bakteri terhadap antibiotik di dunia menjadi masalah kesehatan global (CDC, 2019). Resistensi terjadi dapat disebabkan oleh dua faktor yaitu resistensi alami dan resistensi dapatan. Menurut Kemenkes RI (2013) beberapa faktor yang dapat menimbulkan masalah dari resistensi bakteri terhadap antibiotik yaitu mudahnya masyarakat mendapatkan antibiotik, kurangnya pengawasan pemerintah terhadap masyarakat tentang, penggunaan antibiotik yang tidak rasional seperti pemilihan antibiotik tidak sesuai dengan kondisi pasien dan pola peresepan antibiotik yang kurang tepat (Pratama et al., 2019).

\footnotetext{
• email korespondensi: fitriamega83@unmas.ac.id
} 
Resistensi bakteri terhadap antibiotik menyebabkan berkurangnya efektivitas terapi Kurangnya sensitivitas antibiotik terhadap suatu bakteri yang membuat bakteri itu semakin kebal yang berdampak peningkatan morbiditas dan mortalitas serta pengeluaran perawatan kesehatan yang berlebihan (Rukmini et al., 2019)

World Health Organization (WHO) berupaya untuk mengendalikan resistensi secara global. WHO telah membuat perencanaan aksi global untuk memerangi resistensi bakteri terhadap antibiotik dengan meningkatkan penggunaan antibiotik secara bijak dan dengan melakukan evaluasi penggunaan antibiotik (WHO, 2017). Resistensi antibiotik adalah kemampuan mikroorganisme untuk bertahan terhadap efek antibiotik, diantaranya dengan memperoleh gen resisten melalui mutasi atau perubahan/ pertukaran plasmid (transfer gen) antar spesies bakteri yang sama (Pratiwi, 2017).

Peta kuman di rumah sakit merupakan laporan pola mikroba pada suatu ruang perawatan yang disajikan dalam bentuk ranking sehingga membantu klinisi dalam memberikan terapi awal sebelum ada hasil kultur bakteri (Wahjono and Kristina, 2008). Pergeseran pola kepekaan menjadi salah satu indikator penggunaan antibiotik di suatu rumah sakit dan merupakan salah satu indikator kinerja kunci (key performance indicator) pelaksanaan program pengendalian resistensi antibiotik di rumah sakit tersebut. Penggunaan antibiotik yang terlalu banyak atau penggunaan secara tidak bijak berdampak pada perburukan profil peta kuman, dan sebaliknya, pengurangan penggunaan antibiotik penggunaan yang bijak akan memperbaiki profil peta kuman sehingga peta kuman di rumah sakit dapat digunakan sebagai salah satu bentuk pengawasan penggunaan antibiotik (Peraturan Menteri Kesehatan Republik Indonesia Nomor 8 Tahun 2015 tentang Program Pengendalian Resistensi Antimikroba di Rumah Sakit, 2015).

Gambaran resistensi bakteri terhadap antibiotik bisa dijadikan untuk evaluasi penggunaan antibiotik yang bijak untuk mengurangi adanya resistensi bakteri terhadap antibiotik. Berdasarkan uraian diatas maka perlu dilakukan suatu penelitian mengenai studi restropektif gambaran resistensi bakteri terhadap antibiotik. Tujuan penelitian ini adalah untuk mengetahui gambaran resistensi bakteri terhadap antibiotik di rumah sakit.

\section{METOdE PENELITIAN}

Rancangan Penelitian. Penelitian ini menggunakan rancangan deskripstif. Penelitian ini menggunakan data peta kuman periode 2019- 2020 di salah satu Rumah Sakit Umum Pemerintah di Denpasar. Pada penelitian ini telah mendapatkan persetujuan etik dari Komisi Etik Penelitian Fakultas Kedokteran Universitas Udayana. No. 613/UN14.2.2 VII.14/LT/2021

Populasi dan Sampel. Populasi pada penelitian ini adalah data penjualan antibiotik di Rumah Sakit Umum Pemerintah di Denpasar pasien rawat inap dan data persentase resistensi bakteri terhadap antibiotik di rumah sakit yang diteliti selama tahun 2019-2020. Penelitian ini menggunakan metode total sampling, yaitu mengambil semua anggota populasi sebagai sampel yang diamati pada periode 2019- 2020.

Teknik Pengumpulan Data. Cara pengumpulan data pada penelitian ini dilakukan secara retrospektif dengan menggunakan data antibiogram atau peta kuman di Rumah Sakit Umum Pemerintah di Denpasar pada periode 2019 - 2020.

Penilaian resistensi bakteri terhadap antibiotik. Resistensi bakteri dapat dilihat dari data persentase resistensi. Berdasarkan kriteria resistensi dapat digolongkan menjadi 3 yaitu Recommended yaitu dengan persentase resistensi $<40 \%$ dapat disarankan untuk terapi). Considered yaitu dengan (persentase resistensi $40 \%$ - $70 \%$ perlu pertimbangan untuk terapi. Dan not ecommended yaitu dengan persentase resistensi $>70 \%$ tidak disarankan untuk terapi.

\section{HASIL DAN PEMBAHASAN}

Penelitian ini bertujuan untuk mengetahui gambaran antara penggunaan antibiotik dengan resistensi bakteri terhadap antibiotik di Rumah Sakit Umum Pemerintah di Denpasar periode 2019- 2020. Pada penelitian yang dilakukan di Rumah Sakit 
Umum Pemerintah di Denpasar data profil sensitivitas bakteri Gram-positif. Gram-negatif pada periode 2019- 2020 pada penyakit pneumonia. Pada antibiotik yang digunakan yaitu Ampisilin Sulbactam, Seftriaksin, Doksisiklin, Sefepim, Meropenem, Siprofloksasin, Levofloksasin, Trimthoprim/ Sulfametoksazol, Sefotaksim, Amikasin.

Resistensi adalah ketahanan suatu mikroorganisme terhadap suatu anti mikroba atau antibiotik tertentu (Artati, Hurustiaty and Armah, 2018). Mekanisme yang menyebabkan bakteri menjadi terhadap antibiotik yaitu, bakteri memproduksi enzim yang merusak daya kerja obat, dimana Staphylococcus resisten terhadap Penisilin disebabkan karenamemproduksi enzim betalaktam penisilin, sehingga penisilin tidak aktif lagi bekerja . Terjadinya perubahan pada metabolic pathway yang menjadi target obat. Bakteri yang resisten terhadap obat golongn Sulfonamida, tidak memerlukan PABA dari luar sel, tapi dapat menggunakan asam folat; sehingga sulfonamida yang berkompetesi dengan PABA tidak berpengaruh apa-apa pada metabolisme sel (Marhamah, 2016).

Total isolate bakteri Gram-positf yaitu 2019 tiga jenis bakteri dengan isolat terbanyak yaitu pada bakteri Gram-positif yaitu bakteri Staphylococus Coagulase Negatif (43\%), Enterococus. sp (10\%), Staphylococcus aureus (26\%). Pada bakteri Staphylococcus Coagulase Negatif resistensi dengan antibiotik sefipem, meropenem dan seftriakson (78,19\%, 79,50\% dan 97,75\%) yang tidak dapat di rekomendasikan untuk terapi dilihat dari tabel 1 . Staphylococcus Coagulase Negatif memiliki sensitivitas terhadap antibiotik Trimethoprim/ Sulfametoksazol, (46.13\%) Siprofloksasin (55.75\%) dan Levofloksasin (55.38\%). Staphylococcus aureus merupakan salah satu bakteri penyebab infeksi terbanyak di dunia (Afifurrahman et al. 2014). Staphylococcus aureus sensitif pada antibiotik ampisilin sulbaktam, Trimethoprim/Sulfametoksazol (21.86\% dan $14.97 \%$ ) yang dapat di rekomendasikan untuk pengobatan. Pada bakteri Staphylococcus aureus antibiotik sefipem perlu pertimbangan untuk pengobatan.

Pada penelitian ini antibiotik yang diujikan lebih dari 300 isolat. Bakteri dengan jumlah terbanyak menyebabkan infeksi yaitu bakteri Escherichia coli (32\%), Pseudomonas aeruginosa (12\%) dan Klebsiella pneumoniae (12\%). Bakteri Escherichia coli memiliki resistensi tertinggi pada antibiotik ampisilin sulbaktam (90.27\%). Escherichia coli ini juga menunjukkan tingkat intermediet terhadap antibiotik seftriakson dan memiliki sensitivitas pada antibiotik amikasin dengan (1\%). Isolat bakteri Escherichia coli ditemukan di Australia menghasilkan carbapenem-hidrolisis b-laktamase. Tingginya tingkat resistensi terhadap aminoglikosida (Sumampouw, 2018).

Hasil penelitian ini menunjukkan bahwa bakteri Pseudomonas aeruginosa masih sensitif pada beberapa antibiotik salah satunya adalah terhadap antibiotik sefoperason sulbaktam (15.49\%) pada tabel 2.

Bakteri Pseudomonas aeruginosa masih sensitif pada beberapa antibiotik salah satunya adalah terhadap antibiotik sefoperason sulbaktam (15.49\%) pada tabel 2. Infeksi Pseudomonas aeruginosa yang tergolong bakteri Gram-negatif, umumnya terjadi pada orang dengan ketahanan tubuh yang menurun. Bakteri tersebut merupakan penyebab infeksi nosokomial terbesar kedua pada golongan bakteri Escherichia coli. Klebsiella pneumoniae memiliki sensitivitas terhadap antibiotik Sefoperason Sulbaktam (17.41\%). Klebsiella pneumoniae intermediet pada antibiotik sefepim (58.2\%).

Pada penelitian yang dilakukan di Amerika Serikat mengenai sensitivitas bakteri Gram-negatif yang diperoleh dari pasien yang dirawat di rumah sakit dengan pneumonia menunjukkan bahwa bakteri penyebab infeksi tersering adalah Pseudomonas aeruginosa berbeda dengan penelitian ini. Pseudomonas aeruginosa adalah bakteri Gram-negatif menunjukkan penurunan kerentanan terhadap sebagian antibiotik, termasuk seftazidim, meropenem. Bakteri Pseudomonas aeruginosa menunjukkan tingkat resistensi yang tinggi pada antibiotik Seftazidim (68.5\%), Gentamisin (71.4\%) dan Ofloksasin (81.7\%) (Gupta et al., 2017). 


\section{SIMPULAN}

Berdasarkan penelitian yang telah dilakukan tiga bakteri Gram-positif penyebab infeksi terbanyak yaitu Staphylococus Coagulase Negatif (43\%), Enterococus. sp (10\%), Staphylococcus aureus (26\%). Bakteri Gram-negatif yaitu Escherichia coli (32\%), Pseudomonas aeruginosa (12\%) dan Klebsiella pneumoniae (12\%). Antibiotik yang masih dapat di rekomendasikan untuk terapi gram-positif, yaitu ampisilin sulbaktam, siprofloksasin dan levofloksasin. Sedangkan pada bakteri Gram-negatif antibiotik yang masih dapat direkomendasikan untuk terapi yaitu Sefoperason Sulbaktam dan Sefepim.

\section{DAFTAR PUSTAKA}

Afifurrahman, A., Samadin, K. and Aziz, S. (2014) 'Pola Kepekaan Bakteri Staphylococcus Aureus terhadap Antibiotik Vancomycin di RSUP Dr. Mohammad Hoesin Palembang', Majalah Kedokteran Sriwijaya, 46(4), pp. 266-270. doi: 10.36706/mks.v46i4.2716.

Artati, A., Hurustiaty, H. and Armah, Z. (2018) 'POLA RESISTENSI BAKTERI Staphylococcus $s p$ TERHADAP 5 JENIS ANTIBIOTIK PADA SAMPEL PUS', Media Kesehatan Politeknik Kesehatan Makassar, 11(2), p. 60. doi: 10.32382/medkes.v11i2.227.

CDC (2019) 'Antibiotic resistance threats in the United States, 2019, Atlanta, GA: U.S. Department of Health and Human Services', Center for Disease control and Prevention, pp. 3,103-104.

Gupta, R. et al. (2017) 'Epidemiology of multidrugresistant Gram-negative pathogens isolated from ventilator-associated pneumonia in ICU patients', Journal of Global Antimicrobial Resistance, 9, pp. 47-50. doi: 10.1016/j.jgar.2016.12.016.
Marhamah (2016) 'Resistensi Bakteri Gram Positif Terhadap Antibiotik Di UPTD Balai Laboratorium Kesehatan Lampung Tahun 2012-2014', Jurnal Analis Kesehatan, 5(1), pp. 467-473.

Peraturan Menteri Kesehatan Republik Indonesia Nomor 8 Tahun 2015 tentang Program Pengendalian Resistensi Antimikroba di Rumah Sakit (2015). Jakarta.

Pratama, N. Y. I. et al. (2019) 'Analisis Penggunaan Antibiotik pada Pasien Rawat Inap Bedah dengan Menggunakan Defined Daily Dose dan Drug Utilization 90\% di Rumah Sakit Universitas Airlangga', Indonesian Journal of Clinical Pharmacy, 8(4), p. 256. doi: 10.15416/ijcp.2019.8.4.256.

Pratiwi, R. H. (2017) 'Mekanisme Pertahanan Bakteri Patogen Terhadap Antibiotik', Jurnal ProLife, 4(3), pp. 418-429.

Rukmini, Siahaan, S. and Sari, I. D. (2019) 'Analisis Implementasi Kebijakan Program Pengendalian (Studi Kasus Di RSUP Dr. Wahidin Sudirohisudo , Makassar)', Puslitbang Humaniora dan Manajemen Kesehatan, 22(2), pp. 106-116.

Sumampouw, O. J. (2018) 'UJI SENSITIVITAS ANTIBIOTIK TERHADAP BAKTERI Escherichia coli PENYEBAB DIARE BALITA DI KOTA MANADO ( The Sensitivity Test of Antibiotics to Escherichia coli was Caused The Diarhhea on Underfive Children in Manado City )', Journal of Current Pharmaceutical Sciences, 2(1), p. 105

Wahjono, H. and Kristina, T. N. (2008) 'Auditing Peta Medan Kuman Dan Antibiogram Sebagai Educated-Guess Penanganan Penyakit Infeksi', Media Medika Indonesiana, 43(1), pp. 17-21.

WHO (2017) 'Global action plan on antimicrobial resistance', World Health Organization, pp. $1-28$. 